\title{
Synthesis of New Azino Fused Benzimidazolium Salts. A New Family of DNA Intercalating
} Agents. I

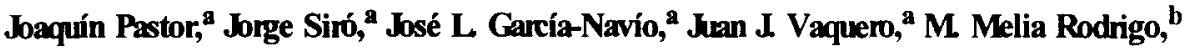 \\ Milagros Ballesteros ${ }^{\mathfrak{c}}$ and Julio Alvarez-Builla ${ }^{\mathrm{a} *}$ \\ Departamentos de ${ }^{a}$ Química Orgónica ${ }^{b}$ Química Füsica, ${ }^{c}$ Quimica Analítica Universidad de Alcalá de \\ Henores. 28871 Alcalá de Henares. Madrid. Spain
}

\begin{abstract}
A series of new pyrido[1,2-a]- and pyridazino[1,6-a]benzimidazolium salts have been synthesized from readily available 1,3-disubstituted 2-alkylbenzimidazolium salts. Their affinity to DNA and in vitro cytotoxicity versus HT-29 have been tested. The initial results show that the title compounds are a new family of intercalating agents.
\end{abstract}

Over the past 25 years, spectacular advances have been made in understanding the interaction of small non-peptide molecules with DNA. ${ }^{1}$ One of the modes of non-covalent DNA-ligand interaction is intercalation. Intercalators are planar molecules, usually consisting of three or four fused aromatic rings, bearing in some cases a positive charge, which are able to insert between stacked DNA base pairs. Most of all reported polyheterocyclic cations with intercalating properties share in common a quaternary nitrogen, usually achieved by alkylation of neutral heterocycles like phenanthridines (Ethidium bromide 1), ${ }^{2}$ pyridocarbazoles (Elliptinium 2 ) $^{3}$ etc. However, there are only few examples where the cationic nitrogen is in a bridgehead position, such as the indolo[1,2-a]quinolizinium alkaloids (Sempervirine 3$)^{4}$ or the imidazodiquinolinium cation $4^{5}$ (Fig. 1).<smiles></smiles>

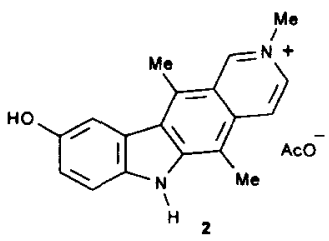<smiles>[R]c1cc2n([R])c3ccccc3[n+]2cc1[Y]</smiles>

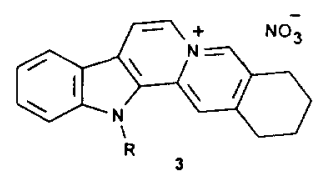

6 $\mathrm{Z}=\mathrm{CH}$

Figure 1<smiles></smiles>

4 
In recent years, we have developed a simple methodology to synthesize polyfused heterocyclic cations with bridgehead nitrogens, by means of a double condensation between a suitable $\alpha$-alkylazinium or azolium salt and 1,2-dicarbonyl derivatives. ${ }^{6}$ In order to obtain functionalized derivatives which could be further manipulated, we focused our attention on the benzimidazolium system as a precursor of fused pyrido and pyridazino salts 5 and 6. This is because the benzimidazole indole-type nitrogen can be easily substituted facilitating, in the case of products showing interesting DNA binding properties, the preparation of new bisintercalator derivatives.

In this communication we report some initial results related with the synthesis and chemical transformations of different pyrido[1,2-a]- and pyridazino[1,6-a]benzimidazolium salts 5 and 6. On the compounds prepared, we carried out the spectrophotometric (UV-Vis) determination of the corresponding affinity constants ${ }^{7}$ as well as viscosimetry of the chromophore-DNA complexes ${ }^{7}$ to prove the intercalation process. Also, to test behaviour of the products on cellular systems, cytotoxic activity against HT-29 colon carcinoma was determined. 8

Chemistry: The title salts have been obtained (Scheme 1) from 1,3-disubstituted 2-alkylbenzimidazolium salts 4 , prepared from commercial or easily available 1-substituted 2-alkylbenzimidazoles, by quaternization with ethyl bromoacetate $\mathbf{4 a}, \mathrm{b}\left(\mathrm{X}=\mathrm{C}-\mathrm{CO}_{2} \mathrm{Et}, \mathrm{R}^{\mathrm{l}}=\mathrm{H}, \mathrm{Y}=\mathrm{C}-\mathrm{CO}_{2} \mathrm{Et} \text { or } \mathrm{C}-\mathrm{Ph}\right)^{9}$ or O-hydroxylaminomesitylenesulfonate (MSH), $4 \mathbf{c}-\mathbf{k}\left(\mathrm{X}=\mathrm{N}, \mathrm{R}^{1}=\mathrm{H}, \mathrm{Ph}\right.$ and $\mathrm{Y}=\mathrm{C}-\left(\mathrm{CH}_{2}\right)_{\mathrm{n}}-\mathrm{CO}_{2} \mathrm{Et}, \mathrm{C}-\mathrm{Ar}, \mathrm{C}_{-} \mathrm{CH}_{2} \mathrm{NHCOCH}_{3}$ or N$) .^{10}$ Basic condensation of salts 4 with 1,2-diketones ${ }^{11}$ yielded the corresponding pyrido[1,2-a]- and pyridazino[1,6-a]benzimidazolium salts $\mathbf{5 a} \mathbf{b}$ and $\mathbf{6 a - k}$ respectively (Table 1).

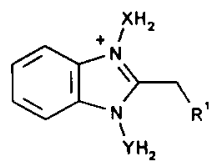

4

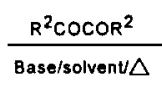

Scheme 1

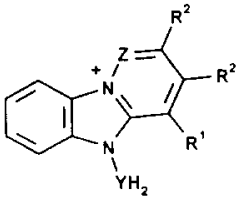

$5 \mathrm{Z}=\mathrm{C}-\mathrm{H}$ or $\mathrm{C}-\mathrm{CO}_{2} \mathrm{Et}$

$6 Z=N$

When one of the nitrogen substituents of the in the starting salt $\mathbf{4}$ is an amino group, the condensation takes place regioselectively to produce the pyridazino derivatives 6 .

Since the presence of amino or amido functionalities usually increases the affinity to DNA, ${ }^{12}$ we tested the conversion of the ethoxycarbonyl group in 6 into the corresponding amido derivatives. As an example, treatment of $6 \mathrm{~b}$ with simple amines, such as n-propylamine, produced the amide 61 , but only in good yield when the amine was in high excess or as solvent. Similar reaction with 1,2-diaminoethane yielded the monoamide $7 \mathbf{a}(\mathrm{n}=2)^{13}$ (Scheme 2). This compound, with both amino and amido groups in the side chain, could be of great interest not only because both groups should contribute to improve the affinity to DNA, but also because it can be used as precursor of the corresponding bis-salts, interesting as bisintercalators. 
When a longer aliphatic diamine, as 1,8-diaminooctane, was used in the same experimental conditions (excess of diamine, and reflux), instead of the monoamide $7 b(n=8)$, the reaction product was identified as the bis-salt $8 b^{14}(n=8)$. Although the experimental conditions (high molar ratio between the amine and the heterocyclic salt $\mathbf{6 d}$ ) should not have favoured the formation of the bis-salt as the major product, its separation from the reaction mixture as a highly insoluble product, could had contributed, to shift the equilibrium. Additionally, a shorter diamine as 1,4-diaminobutane, produced mixtures of monoamide $7 \mathrm{c}$ and bis-salt $8 c(n=4)$, suggesting that the electrostatic repulsion between both cationic nuclei controls the formation of the bis-amide derivatives, thus justifying the only detection of the monoamide $7 \mathrm{a}$ in the experiments with 1,2-diaminoethane.

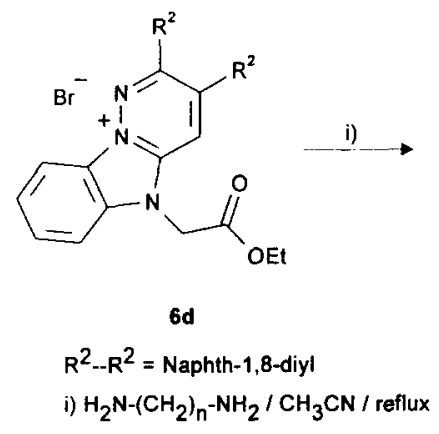

Scheme 2

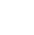

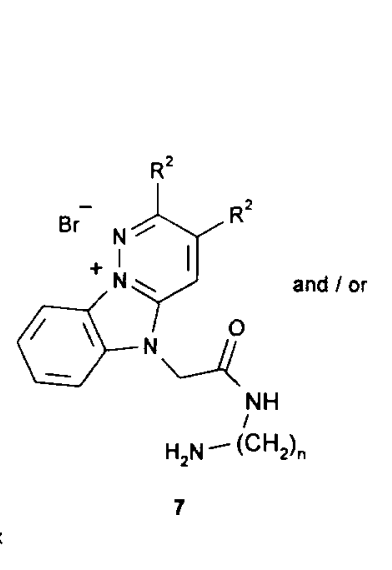

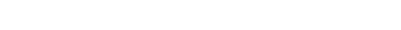

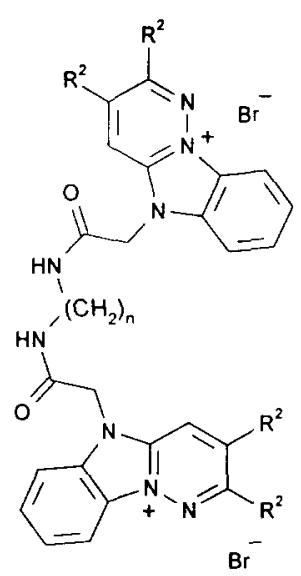

8

Results and Conclusions: Biological data and a brief description of the tests used to evaluate the salts $\mathbf{5}$, 6 and 7 are found in Table 1.

UV/Vis spectrophotometry. A preliminary test for all compounds was performed by comparing free versus DNA bound product UV-Vis spectra. ${ }^{15}$ This test allowed us to eliminate i.e., those derivatives bearing alkyl substituents in the pyridazino moiety, because none of them showed changes in the corresponding UV spectra before and after DNA addition. Three initial conclusions were deduced: a) a minimum number of four linearly fused rings were needed to interact with DNA, b) steric hindrance produced by alkyl groups on the flat aromatic system, affects negatively the interaction, and c) the naphthalene-1,8-diyl moiety on $\mathrm{R}^{2}$, seems to favour the interaction.

In a second step, we measured the DNA affinity constants $(\mathrm{K})$ for some of the selected salts, by UV-Vis titration of its diluted solutions with DNA, as reported by Cory et al. ${ }^{7}$ As it is shown in Table 1 , the Kvalues for salts 5,6 and 7a, with the exceptions of $6 \mathrm{~h}, \mathrm{~g}, \mathrm{~h}$ and $6 \mathrm{j}$ lie in $10^{5}-10^{10} \mathrm{M}^{-1}$ range, as observed for most common intercalating agents. ${ }^{16}$ The N-methyl salt $6 a^{6 c}\left(\mathrm{~K}=3.510^{5} \mathrm{M}^{-1}\right)$ was used as reference for all products, showing one of the best $\mathrm{K}$-values. Replacement of the $\mathrm{N}$-methyl group with a benzyl 


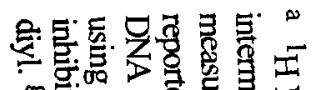

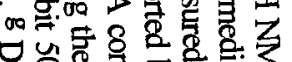
\%

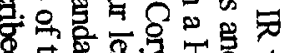

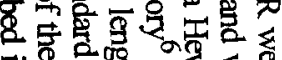
5.

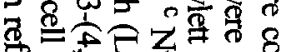

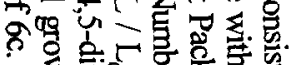

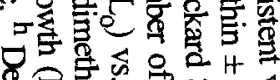

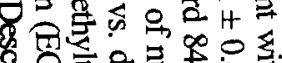
을을 造

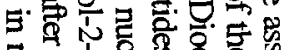
茟

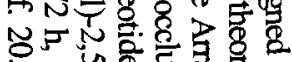

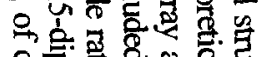
8 흘. 을

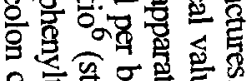

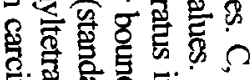
훙 형 5

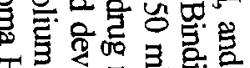

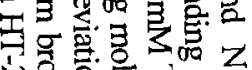

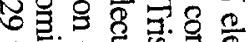

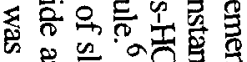
\&

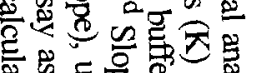

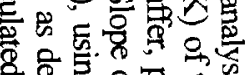

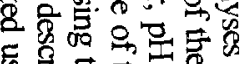

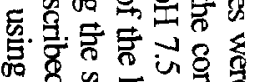
5 舟

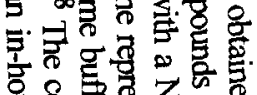

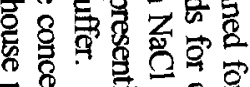

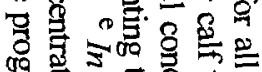

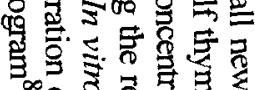

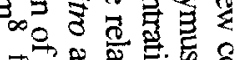

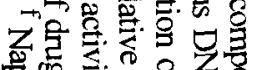

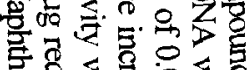

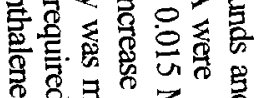

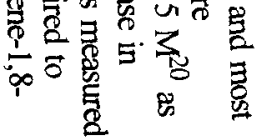

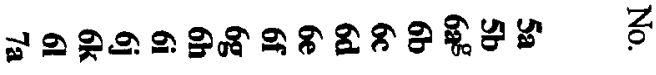

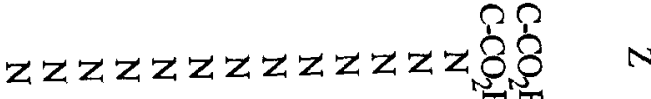

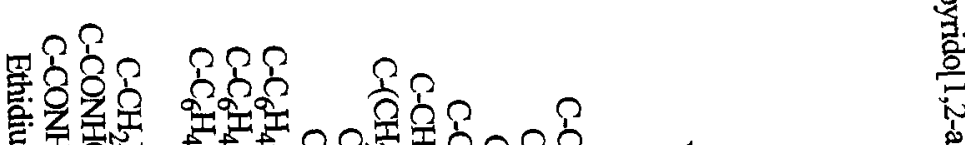

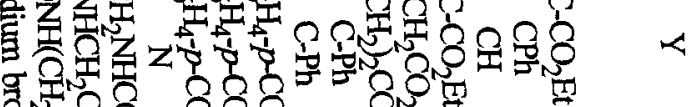

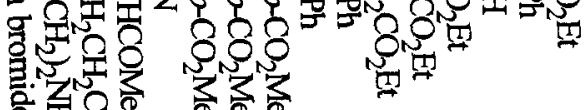

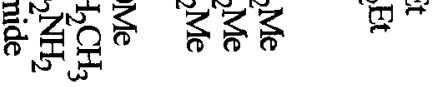

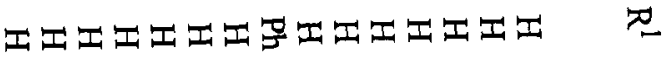

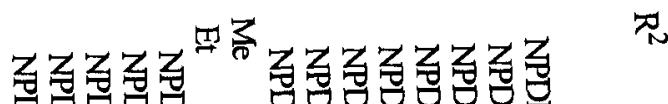

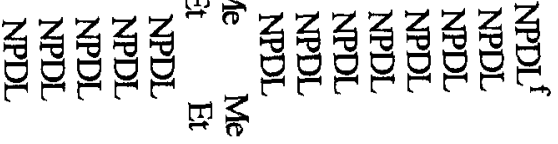

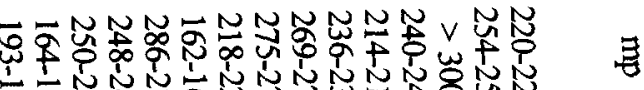

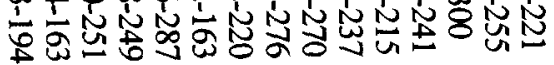

$N$

办

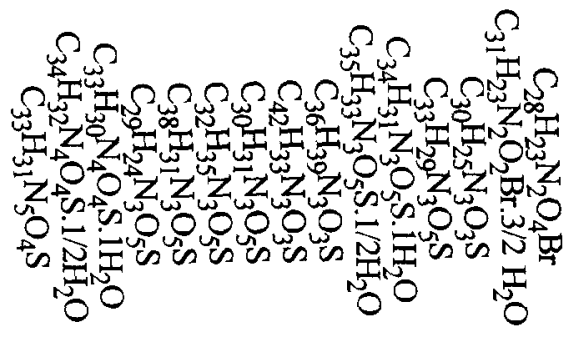

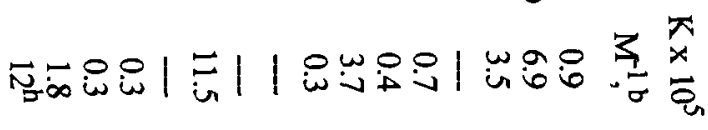

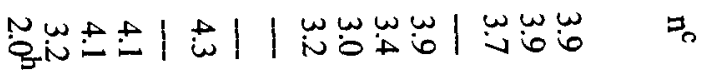

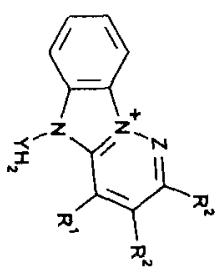

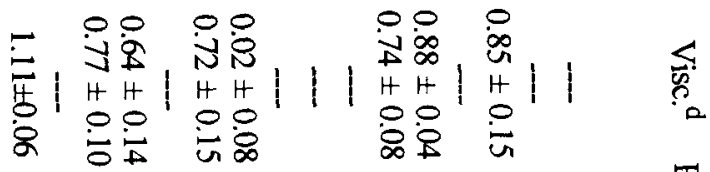

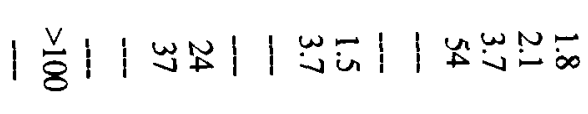


moiety maintains or increases the affinity toward DNA (3.72 for 6 and $11.510^{5} \mathrm{M}^{-1}$ for $\left.6 \mathrm{i}\right)$. A similar result was observed with the pyrido derivatives $\left(6.9310^{5} \mathrm{M}^{-1}\right.$ for $\left.5 \mathrm{~b}\right)$. Finally, another interesting compound is the amino derivative $7 \mathrm{a}\left(1.8410^{5} \mathrm{M}^{-1}\right)$. The bis-salt $8 \mathrm{~b}$ was insufficiently soluble for reliable data to be obtained, and precipitation of partially soluble complexes occurred in various common buffers. Viscosimetry One characteristic of intercalative binding to DNA is the length increase resulting when a drug intercalates, producing a change in the viscosity of the sonicated DNA solution. Although relationship between viscosity and DNA length increase on intercalation is more complicated than expected, ${ }^{17}$ viscosimetric determination gives a semiquantitative measure of length change. The slope of the line representing the relative increase in DNA contour length $\left(\mathrm{L} / \mathrm{L}_{0}\right)$ vs. drug/nucleotide ratio can be reproducibly determined (Table 1 ) and provides a simple and theoretically sound mean of distinguishing DNA binding mode. The values obtained for our compounds are characteristic from intercalators, being the lower observed slopes due to the different buffer used in our experiments. ${ }^{18}$

Finally, except in the case of the dialkyl derivatives $\mathbf{6 h \mathbf { h }}$, where the interaction with DNA do not exist, results are comparable to those reported for classical intercalators $(1.11 \pm 0.06$ of standard deviation of the slope, for ethidium bromide 2 used as a reference) with slight differences depending of the nature of substituents. In Vitro Cytotoxicity versus HT-29. ${ }^{8}$ - Some of the described salts, 5a,b and 6a,e,f showed activities against colon carcinoma $\mathrm{HT}-29$ cells $\left(\mathrm{EC}_{50}: 1.8,2.1,3.7,1.5\right.$ and $3.7 \mu \mathrm{M}$ respectively) in the same order of the well known agent doxorubicin $\left(2.3 \mu \mathrm{M},{ }^{19}\right)$.

In summary, a family of new DNA intercalating quaternary heterocycles have been described. The versatility of the substitution in the indole-type nitrogen, will allow the development of future series of bisintercalating dimers, based in the same chromophores, by the use of the suitable $\alpha, \omega$-difunctionalized linker chains, giving an easy access to highly selective DNA-interacting compounds.

Acknowledgment. Authors wish to acknowledge the Spanish Comisión Interministerial de Ciencia y Tecnologia (project SAF 94-0280) and the University of Alcalá (Madrid, Spain) for financial support, and to Dr. M. Fernandez Braña and Knoll S.A., by performing the $i n$ vitro cytotoxycity tests.

\section{References and Notes}

1. Nucleic Acid Tangeted Drug Design; Propst, C. L. and Perum, T. J. eds.; Marcel Dekker Inc.: New York, 1992.

2. Wakelin, L. P.; Waring, M. J. J. Mol. Biol., 1980, 144, 183.

3. a) Gribble, G. W. in The Alkaloids; Brossi, A. ed.; Academic Press; New York, 1990, 39, 239. b) Meunier, G.; de Montauzon, G.; Bernardou, J.; Grassy, G.; Bonnafous, M; Cros, S.; Meunier, B. Mol. Phamacol. 1988, 33, 93.

4. Caprasse, M; Houssier, C. Biochimie 1984, 66, 31.

5. Feigon, J.; Denny, W. A.; Leupin, W.; Dearns, D. V.; J. Med. Chem., 1984, 27, 450.

6 a) Santiesteban, I.; Siro, J. G.; Vaquero, J. J.; García-Navio, J. L.; Alvarez-Builla, J.; Castaño, O.; Andrés, J. L. 
J. Ong. Chem. 1995, 60, 5667. b) Diaz, A.; Matia, M. P.; García-Navio, J. L.; Vaquero, J. J.; Alvarez-Builla, J. J. Org. Chem. 1994, 59, 8294. c) Matia, M. P.; García-Navío, J. L.; Vaquero, J. J.; Alvarez-Builla, J. Liebigs Ann. Chem., 1992, 777. d) Matia, M P.; Ezquerra, J.; Sanchez-Ferrando, F.; García-Navío, J. L.; Vaquero, J. J.; Alvarez-Builla, J. Tetrahedron. 1991, 47, 7329. e) Matia, M. P.; Ezquerra, J.; Garcia-Navio, J. L.; Vaquero, J. J.; Alvarez-Builla, J. Tetrahedron Letts. 1991, 32, 7575.

7. Cory, M.; McKee, D. D.; Kagan, J.; Henry, D. W.; Miller, J. A. J. Am. Chem. Soc. 1985, 107, 5518

8. Braña, M. F.; Castellano, J. M.; Morán, M.; Pérez de Vega, M. J.; Romerdahl, C. A.; Quian, X-D.; Bousquet, P.; Emling, F.; Schlick, E.; Keilhauer, G. Anticancer Drug Res., 1993, 8, 257

9. Compounds 4a, b were prepared as follows: Equivalent amounts ( $10 \mathrm{mmol})$ of the corresponding 1substituted 2-methylbenzimidazole and ethyl bromoacetate in dry acetone $(30 \mathrm{~mL})$ were refluxed for 4 h. The precipitate was collected and recrystallized from absolute ethanol.

10. Compounds $\mathbf{4 c - k}$ were prepared as follows: To a stirred solution of O-Mesitylenesulfonylhydroxylamine (MSH) $(2.15 \mathrm{~g}, 10 \mathrm{mmol})$ in dichloromethane $(20 \mathrm{~mL})$, the corresponding 1,2-disubstituted benzimidazole $(10 \mathrm{mmol})$ in the same solvent $(20 \mathrm{~mL})$ was dropwise added. The mixture was stirred at room temperature for $10 \mathrm{~min}$. Diethyl ether $(30 \mathrm{~mL})$ was then added to precipitate the $\mathrm{N}$ aminobenzimidazolium salt, which was triturated with the same solvent $(3 \times 5 \mathrm{~mL})$ and recrystallized from absolute ethanol.

11. Compounds 5a, b and 6a-k were prepared as follows: Equivalent amounts (10 mmol) of the corresponding benzimidazolium salts 4 , the dicarbonyl derivative, and anhydrous sodium acetate $(0.82$ g) were suspended in dry acetone (or ethanol for $6 \mathrm{j}$ ) $(10 \mathrm{~mL}$ ). The mixture was stirred for $6 \mathrm{~h}$ and the precipitate filtered and recrystallized from methanol.

12. Wakelin, L. P. G.; Waring, M. J. Mol. Pharmacol., 1974, 10, 544.

13 A solution of ester $6 \mathrm{~d}(1 \mathrm{mmol})$ and ethylenediamine $(0.6 \mathrm{~g} ., 10 \mathrm{mmol})$ were refluxed $(18 \mathrm{~h})$ in dry acetonitrile $(10 \mathrm{~mL})$ and dry pyridine $(0.79 \mathrm{~g}, 10 \mathrm{mmol})$. The precipitate was filtered and washed with acetonitrile $(20 \mathrm{~mL})$ and then recrystallized from methanol.

14. This bis-amide was obtained by refluxing the ester $6 \mathrm{~d}(0.6 \mathrm{~g}, 10 \mathrm{mmol})$ with 1,8 -diaminooctane $(2.88$ $\mathrm{g}, 20 \mathrm{mmol})$ in dry acetonitrile $(10 \mathrm{~mL})$ for $18 \mathrm{~h}$. The precipitate was filtered and washed with warm acetonitrile $(2 \times 10 \mathrm{~mL})$. The solid was suspended in ethanol and made acid $(\mathrm{pH} \approx 2)$ with conc. $\mathrm{HBr}$. The bis-bromide was isolated by filtration and washed with diethyl ether.

15. Binding commonly results in hypochromism and a shift to longer wavelength of the intercalated chromophore transition. Dougherty, G.; Pigram, W. J. CRC Crit. Rev. Biochem. 1982, 12, 103. Berman, H. M; Young, P. R. Annu. Rev. Biophys. Bioeng. 1981, 10, 87.

16. Pindur, U.; Haber, M; Sattler, K. J. Chem. Ed. 1993, 70, 263.

17. Butour, J. L.; Delain, E.; Coulaud, D.; Le Pecq, J. B.; Barbet, J.; Roques, B. P. Biopolymers, 1978, 17, 873.

18. Cory, M.; Tidwell, R. R; Fairley, T. A. J. Med. Chem. 1992, 35, 431.

19. Braña, M. F., personal communication.

20. Graves, D. E.; Watkins, C. L.; Yielding, L. W. Biochemistry 1981, 20, 1887. 